\title{
El audiovisual como dispositivo que da entidad y visibilidad a los "desaparecidos», o el caso de los «desaparecidos aparecidos»
}

Reseña de film: Una flor para las tumbas sin nombre

Verónica Aravena

FHUC, UNL

En la semana del i6 al 2i de mayo se proyectó en el Cine América de nuestra ciudad el largometraje Una flor para las tumbas sin nombre, un film de Daniel Hechim que contó con la participación de más de ochenta santafesinos en su producción, entre realizadores, técnicos y extras, muchos de ellos alumnos y docentes del Instituto Superior $\mathrm{N}^{\mathrm{o}}$ Io de Cine y Artes Visuales de Santa Fe. El documental se rodó en las ciudades de Melincué, Santa Fe, Rosario y Buenos Aires.

En 1976, los cuerpos acribillados de una pareja fueron encontrados a la vera de un camino rural en la localidad de Melincué. El film es la historia de cómo esta comunidad preservó la memoria de estos dos jóvenes víctimas de la dictadura militar argentina (1976-1983) durante más de treinta años.

La película comienza mostrándonos Melincué, una localidad del sur de la provincia de Santa Fe situada a $120 \mathrm{~km}$ de Rosario cuyo apogeo turístico se perdió con las inundaciones periódicas sufridas en los decenios finales del siglo xx. Hechim se detiene varias veces en la belleza de los paisajes de su laguna con imágenes del pasado (fotos, filmaciones caseras) y del presente (capturadas por una cámara fija).

El director establece un contrapunto narrativo entre elementos de ficción y no ficción. Se vale, por ejemplo, de una dramatización del audio original de las 


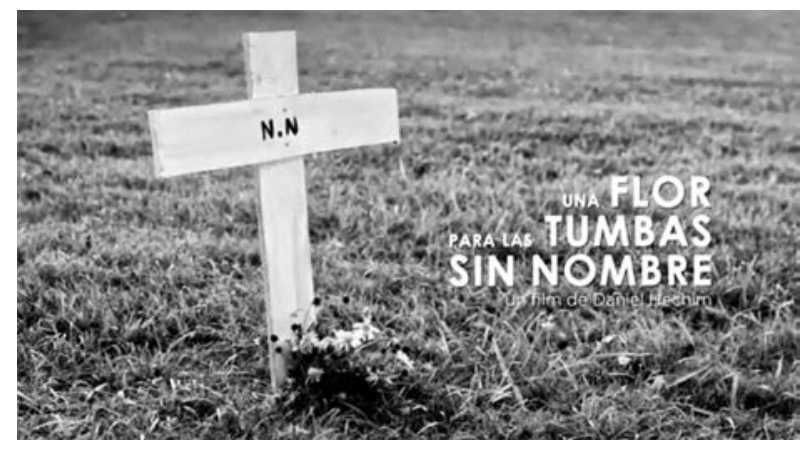

grabaciones que Yves Domergue ${ }^{1}$ enviaba a su familia en 1975 contándoles su vida como estudiante y lo que sucedía en Argentina. Este recurso permite situar al espectador en un clima de época, poniendo de manifiesto el entorno de creciente violencia en los años previos al golpe militar del ' 76 .

Por otro lado, utiliza imágenes de archivo a manera de separadores en el relato para señalar los cambios en el contexto histórico argentino; así observamos los discursos de distintos actores políticos y militares centrales, a saber: Isabel Martínez de Perón, Emilio Massera, Raúl Alfonsín y Néstor Kirchner.

Ocupa un lugar destacado en el documental el recurso artístico a dos siluetas de contorno negro que representan los cuerpos de los desaparecidos; éstas se muestran una y otra vez en el paisaje y lle- gan a conformar parte de la escenografía. La referencia a este significante empleado históricamente por los grupos de defensa de los derechos humanos es clara como forma de simbolizar gráficamente «la presencia de una ausencia».

La fuerza dramática de esta historia reside, sobre todo, en los testimonios de los entrevistados (familiares de los desaparecidos y habitantes de Melincué que participaron en su búsqueda) cuando expresan sus experiencias personales en este derrotero, con sus idas y vueltas, sus desilusiones y sus encuentros. La trama se estructura siguiendo las pistas a través de los años, de la misma manera que lo hicieron sus protagonistas. Juntos escribieron un final inesperado, diferente de aquel pergeñado en 1976 .

En este punto podemos acudir a determinadas categorías analíticas que 
nos brindan las ciencias sociales para reflexionar sobre el texto fílmico que nos ocupa. En particular el concepto de "desaparecido", entendido como una construcción material y simbólica de la última dictadura militar Argentina.

Una de las características centrales de este mecanismo represivo, aplicado a todo individuo que se considerase opositor a las ideas sostenidas por el régimen cívico-militar, era la detención por tiempo indeterminado y de manera clandestina. Entonces las distintas formas de ocultamiento de las personas y/o de sus cuerpos — «vuelos de la muerte», cremación, fosas comunes- pueden ser comprendidas como un método para perpetuar este estado indefinido. De este modo, la persona detenida ilegalmente se transforma en un «desaparecido", pierde entidad, permanece en el anonimato y es, fundamentalmente, una incógnita permanente.

Tal como declaran los familiares de los jóvenes hallados en Melincué - Yves Domergue y Cristina Marulli- esa larga pesquisa les ha permitido identificar estos complejos mecanismos, rastrear a «un desaparecido» implicó a lo largo de sus vidas y sus indagaciones pasar de la incertidumbre a la esperanza, de la negación a la resignación, de la bronca a la impotencia.

Además, según nuestros marcos culturales, la imposibilidad de recuperar el cuerpo de un ser querido colocó a estas personas frente a un penoso dilema: cómo despedirse, cómo hacer el duelo, cómo estar seguras de su muerte.

En este sentido, podemos arribar a la siguiente conclusión: mantener la duda acerca del paradero de estos sujetos, ocultar sus cadáveres, abandonarlos lejos del sitio donde fueron asesinados, se constituyeron en mecanismos y estrategias pensadas específicamente para disociar las identidades de sus cuerpos.

Precisamente, estas prácticas de desaparición forzada de personas se proyectaban desde las esferas del Estado y del poder sobre la sociedad en su conjunto. Su objetivo era, desde el momento del secuestro, separar al individuo del tejido social, aislarlo, evitar cualquier posibilidad futura de volver.

Sin embargo, los supuestos que, desde el discurso, sostenían estas prácticas - a partir de frases como "algo habrán hecho», "no te metás», «ellos se lo buscaron»fueron puestos en tela de juicio por la propia sociedad, pero esto llevó mucho tiempo y forma parte del proceso de transición democrática que atravesó nuestro país en las décadas finales del siglo Xx.

He aquí una de las singularidades de esta historia admirable. Esos supuestos fueron discutidos por la comunidad de Melincué desde el primer momento. Nunca trataron los cuerpos de Cristina e Yves como «desaparecidos» sino como personas; nunca les fue negada su identidad, al contrario, quedó establecido que era desconocida circunstancialmente. 


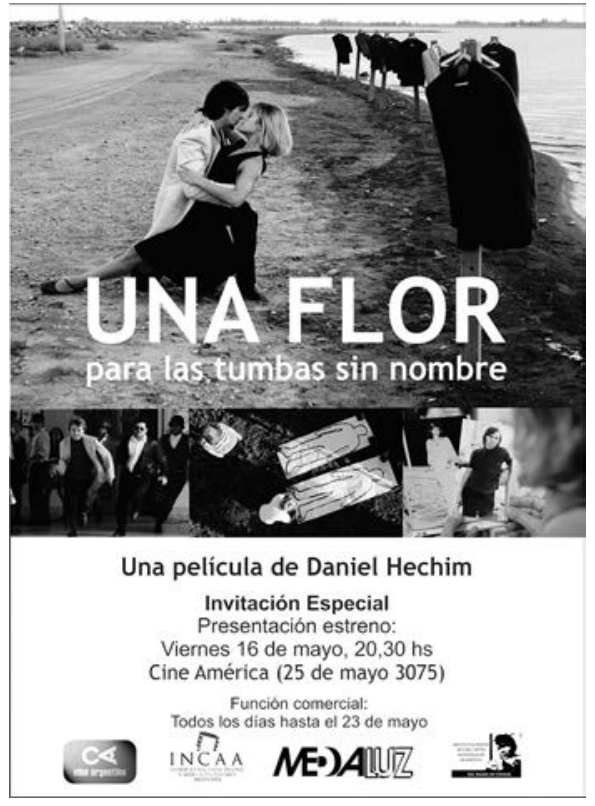

Resultan significativas las palabras de Beatriz Buitron ${ }^{2}$ cuando declara: «Nosotros teníamos que saber quiénes eran». La unión de actos solidarios que entretejieron esta trama nos permite reflexionar acerca del proceso de producción social de la memoria, definido como un ejercicio activo de asignación de significados.

Esta pareja de desaparecidos aparecidos fue sepultada como NN en 1976, pero hubo algunas personas del lugar que lle- varon flores a sus tumbas, otras recordaron el sitio exacto del enterramiento después de las inundaciones, una generación posterior realizó una investigación escolar sobre este suceso, un empleado judicial protegió el expediente del caso a lo largo de los años. ${ }^{3}$ La sociedad de Melincué se apropió simbólicamente de estos muertos y mantuvo vivo su recuerdo.

Contemplamos aquí la producción colectiva de una memoria como construcción cultural, social y aun política, porque la misma desarticuló al «desaparecido" tanto en su dimensión simbólica (contradiciendo sus supuestos discursivos) como en su faceta material. Años después, el caso llegó al Equipo Argentino de Antropología Forense, el cual realizó prácticas de identificación sobre los cuerpos preservados en Melincué cuyo resultado dio con la identidad de Cristina Marulli e Yves Domergue.

Corresponde ahora destacar el valor de este film visto como un bien cultural, el cual aporta representaciones alternativas sobre nuestro pasado reciente. El lenguaje cinematográfico nos aproxima a la historia desde un lugar diferente; donde una pausa, una mirada o un silencio con-

2. Hija del chacarero que encontró los cuerpos en las afueras de su campo en Melincué.

3. Jorge Basuino es el empleado de Tribunales que ingresó el expediente esa noche de 1976 y se encargó de "protegerlo" durante años, cambiándolo de lugar frecuentemente para preservar las pruebas allí contenidas (huellas dactilares, señas particulares de los cadáveres, etc.) hasta que pudiera proseguir su investigación. 
mueven al espectador sobre todo como ser humano.

Pero esta película no sólo nos emociona, también nos invita a reflexionar como sociedad que perdió a muchos de su integrantes en la década del '70. El cine documental se transforma entonces en agente de la historia, en artífice. Lo hace cuando distingue sujetos sociales y sus luchas, cuando visibiliza prácticas sociales, cuando instala el debate en el campo cultural.

La reconstrucción que toda sociedad realiza de su pasado es una arena de disputa permanente. El hecho de poder incorporar estas memorias, de distintos actores sociales, enriquece sin dudas nuestra comprensión histórica y nos acerca a una visión más polifónica de la realidad.

Ficha técnica de la película

Una flor para las tumbas sin nombre

- Duración: 82 minutos

- Dirección: Daniel Hechim

- Guión: María Eugenia Bertone y Daniel Hechim

- Producción: María Eugenia Bertone

- Fotografía: Atilio Perín

- Música original: Gerónimo Piazza

- Edición: Gustavo Duarte

- Formato: Digital

- Año: 2014

Bibliografía.

- BARRIONUEVO, Adriana; BAITÁN, Ariela; OLMO, Darío; SCHERMAN, Patricia (Comp.). Identidad, representaciones del horror y derechos humanos. Cba. 2008. Ed. Encuentro.

- FERRO, Marc. Historia contemporánea y cine. Barcelona. 1995. Ariel Historia.

- JELIN, Elizabeth. Los trabajos de la memoria. Madrid y Bs. As. 2002. S XXI.

.SCHWARZSTEIN, Dora "Memoria e Historia". En Desarrollo Económico Vol. 42. N 167. Bs As. 2002. 
